\title{
Socialist and Post-Socialist Mongolia
}

Nation, Identity, and Culture

\section{Edited by Simon Wickhamsmith and Phillip P. Marzluf}

First published in 2021

\section{D. Natsagdorj, Mongolian travel writing, and ideas about national identity}

\author{
Phillip P. Marzluf
}

(CC BY-NC-ND 4.0)

This OA chapter is funded by Peggie Post, Department of English, Kansas State University, 1612 Steam Place, Manhattan, KS 66506, USA. 


\title{
3 D. Natsagdorj, Mongolian travel writing, and ideas about national identity
}

\author{
Phillip P. Marzluf
}

Within ten years of the death of D. Natsagdorj, the members of the Committee of Mongolian Writers (Mongolyn Zokhiolchyn Khoroo) had begun the process of codifying him as the national writer of the People's Republic of Mongolia. In 1945, eight years after the death of the poet, the Committee of Mongolian Writers sponsored the publication of a slim volume of his work; at the inaugural Conference of Mongolian Writers in 1948, Natsagdorj was declared the nation's first "realist" writer (Sodnom 1966, 5-6). Despite his troubling aristocratic association Nastadorj's father was a taiji, one who could trace his lineage back to Chinggis Khaan (see Sodnom 1966) - Natsadorj was later installed as an important model for socialist children, who would recite his "Pioneers' Song" (Pionyeriin Duu), "My Homeland" (Minii Nutag), and other poems. In a 1980s Reader (Unshikh Bichig), primary-level students were introduced to a short biography about Natsagdorj and exhorted to follow his example: "Like this famous writer, D. Natsagdorj, you children need to study and fulfill great things for your mother country and people" (Sharav 1984, 138). The school system and other youth-related organizations inspired young readers and writers by promoting such awards as the Natsagdorj Pin (Natsagdorj Temdeg) ("Byambajargal" 2013). Furthermore, throughout the second half of the socialist era, Natsagdorj represented an important part of the symbolic geography of Ulaanbaatar: a statue in his honor was erected in the Children's Park.

Similar to that of D. Sükhbaatar, the military leader and symbolic founder of the modern socialist Mongolian state, whose statue still resides in the center of the Mongolian political world (see Kaplonski 2004), Natsagdorj's image and status as the national writer still play an important role in post-socialist Mongolia. Natsagdorj remains an important part of the Mongolian language and literature curriculum, and he features a great deal in the Mongolian language national examination for secondary school graduates, including this one example from a national examination study guide:

The number of students who don't know the great writer D. Natsagdorj's poems and works by heart is almost nonexistent. How does his famous story, "Old Son," start?

(Battogtokh, Batmönkh, and Altantsetseg 2004, 181) 
Natsagdorj's name and image are still associated with literacy contests, such as the "Best Reader - D. Natsagdorj Distinction" Award sponsored by the Sükhbaatar Aimag Public Library ("Best Reader," 2016). Indeed, beyond the borders of Mongolia, his image and words are used to motivate the second-generation adolescents of Mongolian immigrants living in North America and taking heritage language and cultural courses ("Welcome," n.d.). A telling observation about Natsagdorj's symbolic importance for post-socialist Mongolia is the fact that his statue replaced that of Lenin, which had stood as an important city landmark in front of the Ulaanbaatar Hotel for approximately 50 years. In terms of the geographical symbology of Ulaanbaatar, Natsagdorj has usurped the socialist authority of Lenin.

Given the interests of this book, the ability of Natsagdorj's image to transcend his status as a socialist-era poet constructed by the Soviet-influenced intellectual institutions of the Mongolian People's Revolutionary Party is a remarkable one. Natsagdorj has become a symbol of authentic Mongolian nationalism, this Romantic post-socialist form of identity that rhetorically uses historical authorities, images, keywords, language, and cultural practices to present itself as "authentic," "traditional," universal, eternal, and inevitable. David Sneath (2018) claims that these are dominant and commonsensical strategies for "mapping" Mongolian identity on the geographical territory of twentieth- and twenty-firstcentury Mongolia. This position asserts tautologically that Mongolians are Mongolian on the geographical basis of where they reside (i.e., within the boundaries of the Mongolian People's Republic [1924-1990] or Mongolia [1991-present]). They feel united, as citizens, because of ideas of "commonality and solidarity" (Sneath 2018, 35): in addition to geographical territory, they share kinship ties, biology, language, religion, culture, and ways of living, among other possibilities; moreover, they share these identity features across time, linking them to Chinggis Khaan and the formation of the early Mongolian states in the late twelfth and early thirteenth centuries. Natsagdorj, consequently, by which I mean his image - his construction - as much as his writing, is one of these identity features.

My purpose in this chapter is to complicate this dominant, commonsensical approach to Natsagdorj and national identity by examining one of his early poems, "Notes on the Trip to Berlin" (Berlin Yavsan Zamyn Temdeglel), ${ }^{1}$ which he wrote in Berlin in 1927 to describe his travels from Mongolia to Europe. Rather than a comprehensive treatment about Natsagdorj as the national writer of Mongolia and his role in modern Mongolian literature, this chapter limits itself to Natsagdorj as a travel writer who reveals muted and subtle ideas about national identity. What makes this travel poem interesting and significant is its historical context - written on the eve of enormous political and social changes in Mongolia - and its transitional qualities: not only is it demonstrating shifts in poetic forms, but it offers readers glimpses at changes in identity. The fact that "Notes on the Trip to Berlin" is written as rough travel notes and that it presents a fairly clear itinerary of Natsagdorj's travels emphasizes these transitional qualities.

Readers should not consider it an irony that a poem with rich potential for national identity should have been written in Germany, far outside of the territorial 
boundaries of Mongolia, and, moreover, on the modern theme of travel. Travel, as I explore in the following section, helps in the process of constituting national identities by ways of orienting, "mapping," and apprenticing readers - in this case, admittedly, a small and difficult-to-define readership - to their identities that become now more important as the travelers find themselves outside of Mongolia.

This chapter will be divided into five sections. Briefly, I introduce the history of travel writing in Mongolia and outline the main theoretical conversations that constitute travel literature and that are significant for our purposes. Next, I describe the historical context of Natsagdorj's travel to Germany, which prompted the writing of "Notes on the Trip to Berlin," before then analyzing the poem according to its form, genres, and audience(s). In the longest section of the chapter, I analyze the poem as an itinerary - a proto-map - an interpretive move that enables us to discern several potential Mongolian identities offered by Natsagdorj. In the conclusion, I emphasize the way in which Natsagdorj is presented in post-socialist Mongolia to shape new identities based on concepts of land and language.

\section{A brief history and theory of travel literature in Mongolia}

From Western academic scholarship on travel literature, two conversations have important implications for understanding the context of Natsagdorj's "Notes on the Trip to Berlin.” First, according to Tim Youngs (2013), travel literature can fix attitudes and images about non-Western cultures for Western readers; these attitudes and images can become unquestionable and commonsensical tropes (see Spurr 1993) and be highly resilient over time. From the thirteenth century, Western travel writers have shared, circulated, and referenced a consistent set of tropes about Mongolians, Mongolian culture and language, and Mongolian-Han Chinese relationships for Western readers. After the Second Opium War, in the 1860s, North American, North European, and Russian travel in the interior and periphery of the Qing Empire - including Mongolia - became more commonplace. As one hint at Natsagdorj's motivations for writing "Notes on the Trip to Berlin," B. Sodnom $(1961,15)$, Natsagdorj's main biographer during the socialist period, claims that Natsagdorj was familiar with prerevolutionary travel writing in Mongolia. Although Sodnom does not provide specifics about these travel accounts, more than likely Natsagdorj would have come across Ivan Maiskii's 1921 Contemporary Mongolia, a highly unflattering account of Mongolians towards the end of the Autonomous Period (1911-1921), when Natsagdorj studied in Leningrad in 1925. According to Sodnom $(1961,16)$, Natsagdorj sounds a call to action to depart from the feudal, prerevolutionary descriptions of Mongolians and to challenge the tropes that Mongolians were on the verge of "dying out" (Mongolyn golomt mökhökh ni) and were lazy, unclean, and highly superstitious and religious. As we will see, Natsagdorj contributes to a new, active, modern, and independent idea of Mongolian identity, adopting an urban and cosmopolitan identity, one far from the "feudal" tropes that appear in Russian and other Western travel writing.

Similarly, the second conversation from Western scholarship is the importance of paying more attention to the ways in which non-Western travelers, such as 
Natsagdorj, interrupted, challenged, and adapted Western travel writing. Mary Louise Pratt (2008), most notably, asks us to consider the "autoethnographic" writing of non-Westerners, who do not merely erase these Russian, Soviet, or Western imperializing attitudes and tropes, but who blend and adapt these approaches. Pratt writes, "[A] utoethnography involves partial collaboration with and appropriation of the idioms of the conqueror" (7); these attempts by nonWesterners to make their positions more visible are "transcultural" (4), the term Pratt uses to describe the practice of how "subjugated peoples" use and adapt the dominant culture they are exposed to: "While subjugated peoples cannot readily control what emanates from the dominant culture, they do determine to varying extents what they absorb into their own, and what they use it for" (6). In other words, when we examine Natsagdorj's "Notes on the Trip to Berlin," we'll need to be aware of these attempts to transculturally blend Western travel writing with indigenous Mongolian forms and strategies.

We have learned a great deal about the tradition of Mongolian travel writing through Isabelle Charleux's (2015) Nomads on Pilgrimage - yet, that being said, we do not know whether Natsagdorj would have had any contact with these types of travel texts. Charleux $(2015,10,13-15)$ documents the rich genres that constituted the travel of Buddhist monks and pilgrims throughout the Buddhist world of Mongolia, China, and Tibet from the nineteenth century through to the 1930s: travel diaries and travel accounts (orony dans), translations for Mongolians of Chinese "mountain gazetteers," Tibetan guidebooks, and other documents that note the distances between the major places of worship. According to Johan Elverskog (2006), though, these examples of religiously motivated travel, in particular by Inner Mongolians in the nineteenth century Qing Empire, may tell us less about local, indigenous ideas about travel and Mongolian Buddhism and more about the construction of Mongolians as Qing Buddhist subjects, a new identity that interlinked them to the Manchus, Han Chinese, and Tibetans (139): in short, nineteenth-century travel was a way to perform a Qing identity: "Pilgrimage thus became a cult of empire" (122).

\section{The historical and social context of Natsagdorj's "Notes on the Trip to Berlin"}

"Notes on the Trip to Berlin" narrates Natsagdorj's travel in the fall of 1926 through the örtöö (horse relay or post) system in northern Mongolia, westward through the Soviet Union, and then by steam liner to Berlin. Though the narrator and other characters in the poem are not named, it is obviously autobiographical, mentioning obliquely in the final two lines the educational purpose behind the travel: Natsagdorj and Pagmadulam, his wife, travelled to Berlin to participate as students in the Administration for the Mongol Students in Germany and France, a study abroad program that took place from 1926 to 1929, in which approximately 45 students studied in Germany and, to a much lesser extent, France. In May 1926, an initial group of 35 adolescents ( 30 male and 5 female) arrived; they underwent intensive language training in a rural suburb of Berlin before being divided into 
an academic group and a technical training group. The technical training involved cartography and map-making and other practical applications of construction and mechanical sciences such as tannery, lithography and printing, motor mechanics, and brick manufacturing (Wolff 1971, 269-70).

Natsagdorj and Pagmadulam were not a part of this initial group. They arrived in November and were different because they were older (i.e., Natsagdorj was 20 years old) and were married (Wolff 1971, 266-67). Other factors that made Natsagdorj's experience different than those of the other educational program students are the fact that he had earlier studied in Leningrad, having graduated from a military and political academy in 1925 (Sodnom 1961, 12) and being exposed, presumably, to Soviet ideas as well as those of modernist European forms and genres. Furthermore, Natsagdorj already had served informally as his father's secretary in several government ministries from the beginning of the revolutionary period and had leadership positions in two Soviet youth-based organizations, the Young Pioneers and the Union of the Revolutionary Youth (Sodnom 1961, 10-12). Unlike the other students, Natsagdorj was more of a political insider in revolutionary Mongolia, participating in early Mongolian People's Revolutionary Party conferences in 1923 and 1924 (Sodnom 1961, 11). Natsagdorj's aristocratic descent, moreover, was a challenge for a biographer such as Sodnom (1966), who depicted Natsagdorj's father as a poor and unruly taiji to justify Natsagdorj's position as the canonical writer of the socialist state.

According to Serge Wolff (1971), and inconsistent with the socialist hagiographies about the writer, Natsagdorj's experience in Germany was not a success. He was initially placed at the University of Berlin in the Journalism Department yet because of his limited German language skills, he was transferred to the University of Leipzig to work with the Mongolist, Erich Haenisch. Wolff $(1971,267)$ writes that Natsagdorj "seemed to be one of those people who try several things at the same time, not succeeding too well in any of them and who, therefore, blame Fate and the world." In any case, Natsagdorj and Pagmadulam were two of the only four students who failed to remain in the program and did not remain until 1929. For Wolff, the only memorable thing about Natsagdorj was the writer's attempt to teach him Mongolian.

The larger political and historical context of the Administration for the Mongol Students in Germany and France was, from the German perspective, an interest in extending German influence to Central Asia (Wolff 1946, 75). Political leaders of the nascent Mongolian People's Republic, however, desired to find allies beyond that of the Soviet Union and were wary, therefore, of Soviet dominance over this new nation (Christianson 2018). Within a few years, these fears manifested themselves. As Natsagdorj prepared to travel to Berlin, Mongolia's main economic partners consisted of China, Germany, Great Britain, and the United States (Sneath 2018, 26); the economy resembled that of the Soviet Union's New Economic Policy. Yet, by the time the education program students returned in 1929, Mongolia was a far different economic and political polity. The 15th Party Congress in the Soviet Union in December of 1927 reverberated back to 
Mongolian Revolutionary Party officials, influencing the "leftist turn" that led to early - and largely unsuccessful - modernization, literacy, and collectivization movements and to violent assaults on the aristocracy and Mongolian Buddhist institutions. By 1930, 90\% of exports and 75\% of imports were controlled by the Soviet Union (Sneath 2018, 27). Again, Natsagdorj's travel poem and the entire educational program itself played out against a backdrop of intense political and economic maneuvering in Ulaanbaatar and Moscow.

We should hesitate before making too much of the Administration for the Mongol Students in Germany and France as a strategy to counter Soviet political and social infiltration. For one thing, Soviet officials were involved in the early agreements that formed the education program (Wolff 1946, 75), and the program leaders were either Russian speakers or Buryad Russians (Wolff 1946, 76). Furthermore, as a modernization strategy, the educational program was consistent with the aims of Soviet socialist ideology. Whereas the interests in having students trained in building, textile, printing, and mechanical trades is not surprising, Mongolian government officials connected the educational program in Germany with the Mongolian Scientific Committee ${ }^{2}$ to modernize the scientific terminology of the Mongolian language. In an article published for a German audience, the Mongolian head of the educational project, Ishi-Dorji, writes about the scientific and linguistic impetus for the "cultural organization" of the Mongolian People's Republic:

The Mongolian language has proved to be sufficiently capable of development to absorb ideas of the great Indian and Chinese cultures. There is no need to explain that the literature of natural sciences and also of technical character could develop only to a limited degree. . . . Therefore, the creation of a reservoir of terminology and of the literature of exact sciences and technique is today one of the greatest tasks facing the cultural organization of Mongolia.

(qtd. in Wolff 1971, 280)

In one of the earliest renderings of official language policy, Ishi-Dorji claims that the activities of the Terminological Section in the Scientific Committee are a negotiation between accepting new loan words when necessary as well as using "old, already existing terms, as well as in working out and determining new terms, based on the Mongolian language roots" (qtd. in Wolff 1971, 287).

In addition to the development of scientific terminology, the Scientific Committee in its involvement with this European study abroad program emphasized the importance of map-making and the development of modern cartography and cartographic terms, or, in Ishi-Dorji's terms, the "first modern geographical conceptions such as have been developed by European science" (qtd. in Wolff 1971, 283). At a practical level, 1000 large world maps and 10,000 small school atlases were printed in Germany (Wolff 1971, 282). According to Ishi-Dorji, the Scientific Committee also stimulated domestic surveying and explorations to provide 
data for this cartographic development (Wolff 1971, 286). As far as cartographic theorists are concerned, the political implications behind map-making are obvious: maps constitute the nation state. As we will see, travel, forms of wayfinding, and an emerging "cartographic imagination" (Pickles 2004; Smith 2008) become important building blocks of a modern national identity. In summary, the goals of the European study abroad program in which Natsagdorj and other Mongolian students participated were consistent with those of building a modern socialist state and socialist national identity.

\section{Genres, forms, audiences}

"Notes on the Trip to Berlin" consists of 82 stanzas and a total of 324 lines. It encapsulates his travel, beginning on October 17, 1926, through Mongolia (Stanzas 1-20), through Russia (Stanzas 21-63), on the Baltic Sea (Stanzas 64-76), and in Germany (Stanzas 77-82). As an example of travel writing, it is easy to follow Natsagdorj's itinerary through the four days of travel out of Mongolia, which includes stops at ten relay stations. After Natsagdorj boards a train in Üd City (i.e., Ulan-Ude) at two in the morning on October 29, his time markers on the westward train journey towards Leningrad become less clear.

Natsagdorj blends traditional, prerevolutionary pastoral or nature poetry with such modern forms as travel exposition, didactic passages, and socialist or protosocialist exhortations. One example of the natural poetic genre, on which much of his stature as the state poet during the socialist and post-socialist periods is based, is the following description of Lake Baikal:

The water of the lake was deep, quietly lapping,

Blended with the sky in the horizon.

The blackish blue water shone

Layers of waves cast together.

Natsagdorj's interweaves these descriptions of the natural landscape with modern appeals to travel, education, and socialism. Unsurprisingly, the genre of travel exposition constitutes the majority of the lines, including, in the example below, a description of train travel through the center of Russia:

We arrived in Omsk,

Crossed the Irtysh River on a giant bridge,

Kept on traveling west throughout the day and night.

Soon arrived in Sverdlovsk. (Stanza 50)

The didactic and socialist exhortations are far less frequent. Stepping out of his role as nature poet and travel writer, Natsagdorj serves briefly as a geography teacher when he tells his readers that the Volga river links the Caspian Sea to the Neva via a canal (Stanza 52). Taking on the role of a teacher of Soviet 
socialist propaganda, Natsagdorj comments on the expanding nature of agriculture in northern Mongolia, passing a judgement on the modern economic changes (Stanza 9). In the most directly "socialist" passage, which we will return to in the following section, Natsagdorj delivers a paean about Moscow, the capital of the new socialist world:

The warm heart of the new world - Moscow.

The finest place of new learning - Moscow.

It is important to note that except for the genre of travel writing, the other three poetic forms that appear in "Notes on the Trip to Berlin" will play an important role in Natsagdorj's poetry and prose in the 1930s, including for example his first collection of poetry, which was based on didactic health themes and anonymously published in 1935 (Damdinsüren 1961, 5).

This interweaving of traditional and nature-based genres and forms with such modern forms and appeals as travel and socialist-inspired didacticism and exhortation suggests that "Notes on the Trip to Berlin" is a transitional poem, showing shifts not only between traditional and modern forms but between potential forms of national identity. Obviously, Natsagdorj's decision to produce his travel "notes" as poetry and not as dated diary entries or prose travel essays is one factor of this transitional quality. In roughly the same time period in 1927, Natsagdorj returned to the theme of travel in a much shorter and far more personal poem, "A Traveler Going to Study in a Faraway Land" (Natsagdorj 1961, 42), one that replaced the travel exposition with emotional depictions of the landscape. In 1928, Natsagdorj wrote a one-paragraph prose sketch about his European experience. In "May 1 in a Capitalist Country," Natsagdorj invents a Mongolian narrator, Ochir, who is inspired by watching a May Day parade from his "window on the third floor of a building facing a large square in a Western European city" (Natsagdorj 1961, 207). Thus, despite the fact that we are working with little evidence, we can conjecture that Natsagdorj had several strategies available to him to render his travel "notes," and that he depicted this particularly transitional form - a travel poem - to experiment with traditional and modern poetic forms and content.

One example of Natsagdorj's blending of the traditional and the modern is the alliteration of initial sounds or syllables in the headwords. In Stanza 9, in which Natsagdorj comments upon a nontraditional content area, modern agricultural systems, he does so by repeating the initial sound in three of the four lines: "Boroogiin ... Buudai ... Bidnii ..." (see Bawden 2003, xxxv-xxxvi). In addition to this example, in the stanza in which Natsagdorj describes Moscow as the center of the socialist world, he refers readers to the form of the züir üg, the proverb or maxim, a traditional Mongolian form that relies on parallelism and repetition. Finally, the combination of themes of natural beauty with attention to the forms of travel of the early twentieth century is another way of establishing the transitional nature of this poem. In Stanza 30, when Natsagdorj introduces his 
first glimpse of Üd City, he juxtaposes this more mundane modern genre of travel with descriptions of natural beauty:

We rode fast against the icy wind

Smoking cigarettes and talking

Üd City appeared in the haze below a northeastern mountain ridge

Train smoke gushing above a nearby slope.

One additional formal feature of traditional Mongolian poetry that is worth noting is the absence of the individual narrator's point of view. There is no narrative "I," that explicit first-person narrator-as-traveler that, according to travel literature researchers, contributes to the "eye witness account" of travel writing and enhances the credibility of the traveler's experiences (Youngs 2013, 3). In fact, because of the lack of syntactical clues, the translator has several difficult decisions to make: do they invent the "I," creating an observing Natsagdorj narrator? Or, do they preserve the elliptical subject and rely throughout on passive structures? Or, do they adopt a plural "we" perspective? The elliptical narrative also makes it difficult for readers to learn anything about the six Mongolians with whom Natsagdorj traveled. His wife, Pagmadulam, is never mentioned, nor is another one of his travel partners and fellow writer, D. Chimid, who traveled with him on the last leg of the journey, from Leningrad to Berlin. The poem is populated entirely by countryside herders, Buryad farmers, Khalkha youths shivering on the back of Russian carriages, one "Russian woman" (oros ekhner), incomprehensible Germans, Mongolians living in the Soviet Union, and, of course, the young educational program students in Berlin.

Before I turn to the identity potentials that surface in this transitional poem, allow me to make one point about Natsagdorj's audience. Although it is difficult to say with any certainty, Natsagdorj's initial audience was his close friends and writers and, possibly, his fellow students in the educational program. In Chimid's (2016) parallel travel essay, in which he recounts the week of travel with Natsagdorj on the Baltic Sea from Leningrad to Berlin, he also mentions the mysterious "Russian woman" (Stanza 77), though, in this case, she takes on a more prominent role as someone teaching the Mongolian travelers German phrases. The "Russian woman" is most certainly Nina Ivanovna Chistyakova, who will eventually become Natsagdorj's second wife in 1931. The fact that Natsagdorj alludes to the "Russian woman" without any previous mention of her may suggest something about the nature of the intimate readership of his poem: the "Russian woman" only makes sense to readers who are aware of Natsagdorj's social connections. Unfortunately, we do not know enough about Natsagdorj's process of writing this poem, besides the fact that it was completed on August 17, 1927, almost ten months after he arrived in Germany, nor are we aware of whether he circulated drafts of the poem. The original manuscript was archived by the Scientific Committee, where Natsagdorj worked after his return from Germany (Sodnom 1961, 12-13). According to D. Tsedev (2016), it was first published in a 1928 edition of 


\section{Phillip P. Marzluf}

Disciple (Zalgamjlagch), the official publication for the Young Pioneers, before its republication in the various socialist and post-socialist collections of Natsagdorj's works.

\section{Ideas about potential identities}

Natsagdorj's travel poem provides an itinerary, a long list of sequentially ordered proper nouns - cities, train stations, post stations, rivers, mountain passes, and other geographical features - to guide readers from Ulaanbaatar to Berlin. To orient readers, I have listed the itinerary below in the three major phases of Natsagdorj's travel:

Table 3.1 Natsagdorj's Itinerary in "Notes on the Trip to Berlin."

\begin{tabular}{|c|c|c|}
\hline Mongolia (Stanzas 1-20) & Russia (Stanzas 21-63) & Europe (Stanzas 64-82) \\
\hline $\begin{array}{l}\text { Ulaanbaatar City (left } \\
\text { October 17, 1926) } \\
\text { Maanit Pass } \\
\text { Tolgoit Pass } \\
\text { Khüi River Örtöö } \\
\text { Khöndlön River } \\
\text { Burgaltai Örtöö } \\
\text { Khuntsal Örtöö } \\
\text { Boroo River } \\
\text { Khurimt Örtöö } \\
\text { Kharaa Örtöö } \\
\text { Mankhtai Pass } \\
\text { Bayangol Örtöö } \\
\text { Örmögtei Örtöö } \\
\text { Shar River } \\
\text { Khüiten Örtöö } \\
\text { Tömst Pass } \\
\text { Yeröö Örtöö } \\
\text { Yeröö River } \\
\text { Tsagaan Pass } \\
\text { Ivtseg Örtöö } \\
\text { Bürged Mountain } \\
\text { Altanbulag Town (enters on } \\
\text { October 20, 1926) }\end{array}$ & $\begin{array}{l}\text { Troitskosavsk City (i.e., } \\
\quad \text { Kyakhta) } \\
\text { Elst Pass } \\
\text { Selenge River } \\
\text { Galuut Lake } \\
\text { Övgön Place } \\
\text { Üd City (arrived October 27, } \\
\text { 1926) } \\
\text { Selenge River (West of Üd } \\
\quad \text { City) } \\
\text { Lake Baikal } \\
\text { Angar River } \\
\text { Irkutsk City } \\
\text { Angar River } \\
\text { Dood Üd City } \\
\text { Yenisei River } \\
\text { Krasnoyarsk City } \\
\text { Ob River } \\
\text { Novosibirsk City } \\
\text { Omsk City } \\
\text { Irtiysh River } \\
\text { Sverdlovsk City } \\
\text { Asia/Europe Frontier } \\
\text { Kirov City } \\
\text { Volga River } \\
\text { Moscow } \\
\text { Leningrad } \\
\text { Great Neva River } \\
\text { Gulf of Finland } \\
\text { Kronstadt Island }\end{array}$ & $\begin{array}{l}\text { Baltic Sea } \\
\text { Oder River } \\
\text { Shtenin City \& Port } \\
\quad \text { (i.e., Szczecin or } \\
\text { Stettin) } \\
\text { Germany } \\
\text { Berlin } \\
\text { Shtenin Station }\end{array}$ \\
\hline
\end{tabular}

Given this itinerary, it is difficult to say whether Natsagdorj and his readers could interpret the poem with a modern "cartographic imagination," the ability, that is, to conceptualize the nation-state at a more abstract, ideological level 
(Pickles 2004). Unlike Mongolian readers in the second half of the twentieth century, who had been thoroughly socialized into recognizing the Mongolian People's Republic, the Soviet Union, and other nations and geographical areas as abstract entities displayed on maps, Natsagdorj offers an itinerary, a proto-map, a transition from an identity of oneself that is localized to a new modern identity, which has an abstract awareness of one's own country and its relationship with the rest of the world. According to scholars such as John Pickles (2004) and D.K. Smith (2008), maps do not simply reveal the territory that is already out there; they produce a new social identity that interacts with the mapped territory in new ways. For Smith $(2008,6)$, maps provide citizens new ways to imagine and visualize their countries, new perspectives that are no longer local and concrete but now national, political, and abstract. For Pickles (2004), maps affect consciousness and language (12), ordering and domesticating the world (4). Pickles (2004, 4-5) writes, "Maps provide the very conditions of possibility for the worlds we inhabit and the subjects we become."

In this section, I examine the potential of Natsagdorj's "Notes on the Trip to Berlin" as a poem that signals potential urban, national, and socialist-international identities for Mongolians in the early period of the Mongolian People's Republic. By emphasizing Natsagdorj's role as a travel writer - and not as a poet - and on the identity possibilities of "Notes on the Trip to Berlin," we return to one of the goals of the study abroad program to Germany and France: to modernize the Mongolian language, in particular in scientific and cartographic terms, and to produce maps and atlases. In short, recalling Pickles's (2004) and Smith's (2008) associations of mapmaking with national identity, both Natsagdorj's poem and the study abroad program's core goals is to consider the possibility of a new urban, national, and, more tentatively, socialist identity.

First, Natsagdorj rejects grounding "Notes on the Trip to Berlin" with a traditional, pastoral ethnic identity. Other Mongolian literary texts that depict travel in the late 1920s and 1930s, including Dondogiin Tsevegmid's "Ganbat the Student" ("Suragch Ganbat”), M. Yadamsüren's "Three Women” ("Gurvan Khüükhen”), and S. Buyannemekh's "Herder Tovuudai" ("Malchin Tovuudai"), begin first in the countryside and then depict their characters' movement towards Ulaanbaatar and the awakening of their urban subjectivities (see Wickhamsmith 2020). Natsagdorj instead begins his poem in Ulaanbaatar and names it in the fourth stanza, one of the first times Ulaanbaatar is mentioned in a literary text. ${ }^{3}$ Natsagdorj's relationship with Ulaanbaatar, moreover, is a personal one. After he first names the city, he refers to personal terms, including "manai khüree," invoking the name of the city - Ikh Khuree or Niislel Khuree - before 1924. Natsagdorj describes himself as "missing" (sanagalzakh) and "feeling deeply about" (zoolon setgeliin dotor uyaran yoslokh) the city. As the itinerary above indicates, cities play an important emotional role for Natsagdorj, especially when he arrives in the Soviet Union. In Leningrad, for example, where Natsagdorj spent time in 1925 and 1926 as a student, he compares the city to "his welcoming old homeland" (tavtaiyaa khuuchin nutagtaa).

Similar to the ways in which socialist urban identities were later constructed, Natsagdorj does not represent an urban identity as the opposite of a pastoral, countryside 
one. These are complementary identities, in which the countryside authorizes and legitimates ideas about ethnic identity. In several lines, which begin to approximate the didactic style of socialist exhortative rhetoric, Natsagdorj describes the feelings of the Mongolian nomads as aroused by the "wide and beautiful countryside"; the travelers, although they were heading towards a "foreign country," are depicted as "amazed by the happiness of their own homeland" (Stanza 13). Similarly, in Stanza 17, in another exhortative appeal, Natsagdorj announces his pride in the freedom of countryside Mongolians. But, in these lines, Natsagdorj, by the very act of reporting the travelers' observations and feelings about the countryside, subtly separates himself and his fellow travelers from the countryside Mongolians. In the last two lines of Stanza 13, for instance, he uses a parallel construction to separate the possessive phrase "our own homeland's" (ööriin nutgiin) from "foreign country's" (khariin orny): this parallelism emphasizes the fact that Natsagdorj is indeed heading towards Europe and separating himself from his homeland.

In addition to an early invocation of an urban identity, Natsagdorj's "Notes on the Trip to Berlin" projects readers towards a potential European and international identity, one that breaks Mongolia from China and the rest of Asia (see Billé 2015). Of course, Natsagdorj has to consider European and international perspectives to some degree, as these represented his destination and his purpose for travel. Thus, it may be doubtful that Natsagdorj had already deeply internalized modern Soviet ideas as well as Russian cultural attitudes against Asia at the time of writing the poem (see Billé 2015, 7). That being said, Natsagdorj depicts Russia and Germany in quite intimate and nonconfrontational ways. Unlike Western travel writers, who emphasize "contact zones" of difference, in which the travelers and the local interlocutors negotiate linguistic and other cultural differences (Pratt 2008), Natsagdorj rarely confronts his readers with difference. He emphasizes similarities instead. In Buryatia, Natsagdorj claims that the countryside is similar to that of Mongolia (Stanza 24); in Stanza 28, he compares a Buryad Buddhist temple to a Mongolian one; additionally, as Natsagdorj looks out the train window in the middle of Russia, he compares the Kyrgyz Steppe to the Mongolian Gobi (Stanza 48). In other words, Natsagdorj makes these local scenes understandable to his target Mongolian readers. Similarly, Natsagdorj includes very few non-Mongolians in his poem. In southern Buryatia, he passes a group of Mongolian youths shivering on the back of a Russian cart (Stanza 23), and he observes Buryad Mongolians participating in agricultural and pastoral livelihoods (Stanza 24). In Üd City (Stanza 33) and Leningrad (Stanza 56), the narrator runs into Mongolian acquaintances. Consequently, Natsagdorj's version of the Soviet Union is one clearly seen through the intimate perspective of a Mongolian for other Mongolians. It is not until the close confines of the steamship cabin in Leningrad that Natsagdorj, finally, encounters cultural difference. In this case, he emphasizes the strangeness of the language of the German travelers he encounters:

From all sides of the cabin, their nasal sounds shouted out.

"Ja, ja, nein, nein!" and more words that we couldn't understand.

We could only nod our heads and use hand gestures. (Stanza 61) 
It is important to note that Natsagdorj emphasizes this scene of linguistic difference, not mentioning, for example, the role of the "Russian woman" in teaching him German vocabulary (see Chimid 2016). Nor does Natsagdorj focus on how he is perceived by Germans, unlike a Mongolian student who had arrived earlier and had felt as if he and his classmates were a part of a "mobile museum," as they and their traditional Mongolian clothes attracted attention when they arrived (qtd. in Wolff 1946, 76). Natsagdorj writes generally about his interests in the "land, nation, and people" (gazar, oron, khün ardyn baidal), but readers encounter no people until the Mongolian students themselves, who are wearing Western clothing and are interested in hearing about news from Mongolia (Stanza 81).

Finally, Natsagdorj offers a few muted proto-socialist appeals in "Notes on the Trip to Berlin," hinting at the great deal of importance these appeals to modern socialist ways of living and Soviet internationalism would take beginning in the 1930s. Again, at this stage, Natsagdorj's poem is transitional and only nods towards the authority of the Soviet appeals and institutions. As Tsedev $(2016,252)$ notes, Natsagdorj introduces many Mongolized versions of European geographical terms, again hinting at a didactic relationship with his readers and the projection of a modern "cartographic imagination" and identity. Yet, excluding proper nouns, Natsagdorj uses Russian only three times, two of which - "kanal" (canal) and "Budda" (Buddha) - as common loan words, and one of which, "perevoz" (ferry boat), in its Mongolized form, "bervaaz."4 Stanza 56, set in Leningrad, shows an example of this cultural mixing and ideas about transitional or emerging identities, as Natsagdorj emphasizes the "October Hotel" at the beginning of the stanza and then ends it with a visit to the Datsan Gunzechoinei, the local Buddhist temple, or Buddagiin sumiin gazar. Natsagdorj is purposefully, perhaps playfully, juxtaposing a revolutionary Soviet term with a core part of Mongolian religious identity; but, even here, by relying on the non-Mongolian expression of a "Buddha temple," he is perhaps undercutting the force of that particular cultural tradition. Let us close this section by returning to the paean about Moscow. Again, Natsagdorj blends the proto-socialist appeal with the form of traditional Mongolian verse:

The warm heart of the new world - Moscow.

The finest place of new learning - Moscow.

We saw things, opened our eyes.

We studied. Became men. (Stanza 54)

Writing to an audience of socialist Mongolians, Sodnom (1966) makes a great deal out of this stanza, arguing that it showcases the "big brother, little brother" relationship with the Soviet Union, emphasizes the importance of a Soviet education, and reminds readers that Mongolia was the second country to have a communist revolution (60). Sodnom, however, overstates the extent and directness of Natsagdorj's socialist appeals here. As I have been attempting to show in this section, Natsagdorj is only hinting at emerging identities and socialist-based social and economic practices - such as farming (e.g., Stanza 9). He blends together 
different genres and forms - some of which pointing in the direction of the more didactic socialist rhetoric that will influence his work in the 1930s - yet he still invests himself with appeals to an intimate Mongolian ethnic identity, to which he continues to appeal to as he travels towards Berlin.

\section{Conclusion}

Appearing in a Facebook post by the Mongolian Language Center (" "Mongol Khemeekh" "2019) and on the website of the Mongolian School of Colorado ("Welcome," n.d.), two lines of poetry, from the penultimate stanza in "History Poem" (Tü̈̈khiin Shüleg) (Natsagdorj 1961, 192-93), showcase Natsagdorj for a young twenty-first-century Mongolian audience:

A culture, its home language you can't forget

A country you can't separate from until your death.

These lines first forecast Mongolian anxieties on the eve of the Era of Repression in the late 1930s. For post-socialist purposes, these lines can be subsequently recast to express anxieties about globalization and the emigration of Mongolians and the industrialization and environmental degradation of Mongolian landscapes, sources of anxiety that are significant for constructions of post-socialist identities (Billé 2015, 20-21). ${ }^{5}$ Importantly for our interests, Natsagdorj invokes the national language and the country or land, a construction of a core Mongolian national identity that will appear in Z. Dorj's (2011) "Words, Borders, Herds" (Khel, Khil, Mal) and other post-socialist nationalist discourses (see Baabar 2010; Dashbalbar 2008, 3). Returning to Sneath's argument about national identity (see Introduction, this volume), we need to recognize these rhetorical uses of and by Natsagdorj as far from "traditional," "authentic," "primordial," or whatever other concepts motivate post-socialist claims to national identity and the past.

As my analysis of "Notes on the Trip to Berlin" suggests, Natsagdorj experiments with and blends identities, producing an "autoethnography" (Pratt 2008) that depicts an independent Mongolian worldview that is not defined, at least directly, by the Soviet Union and the West. In this transitional travel poem, Natsagdorj explores nascent, emerging urban, national, and international identities, successfully countering the prerevolutionary and Qing-era representations of Mongolians circulated by Russian and other European and North American travel writers. As Natsagdorj travels to Europe, he remains in an intimately Mongolian world, one which welcomes him and in which cultural difference is rarely encountered. Natsagdorj's poem is also "transcultural," in that it blends a "modern," Western theme and genre - travel and the daily notes of the traveler, respectively - with Mongolian poetic forms and appeals to nature and landscapes. As readers continue to examine Mongolianness and the ways in which postsocialist national identities interact with those of the socialist or prerevolutionary past, they may want to explore more fully Natsagdorj as a transitional and 
mercurial figure, one whose status as an emblem of Mongolian authenticity is not as obvious and commonsensical as his central position in the post-socialist language and literature curriculum and in the twenty-first-century symbology of Mongolia may promise.

\section{Notes}

1 In the 1961 edition of Natsagdorj's Works, this poem was titled "From Ulaanbaatar to Berlin."

2 The Scientific Committee, established in 1921, was known in Mongolian as the Philology Institute in the late 1920s; it was renamed the Institute of Sciences in 1930 and then renamed the Academy of Sciences in 1961 (Atwood 2004, 2-3).

3 The name of the capital of the Mongolian People's Republic was officially changed to Ulaanbaatar at the end of 1924.

4 Natsagdorj uses a fourth foreign term, "paar" (a carriage led by a pair of horses), from the German das Paar ("pair").

5 For one Wikipedia contributor, the stanza that includes these two lines appeal to Mongolian nationalism so well that it was erroneously inserted to the end of "My Homeland" (Minii Nutag), a poem that patriotically describes the natural beauty of Mongolia ("My Homeland" 2019).

\section{References}

Atwood, Christopher P. 2004. Encyclopedia of Mongolia and the Mongol Empire. New York: Facts on File.

Baabar. 2010. "Don't Forget!” [Büü Mart!] In The History of Mongolia, edited by David Sneath and Christopher Kaplonski, vol. 3, translated by D. Sühjargalmaa, 1028-38. Leiden, Netherlands: Brill.

Battogtokh, D., S. Batmönkh, and B. Altantsetseg, eds. 2004. Mongolian Language Graduation Examination [Tögsölt Elseltiin Mongol Khelnii Sorilgo]. Ulaanbaatar: Ministry of Education, Culture, and Science.

Bawden, Charles. 2003. Mongolian Traditional Literature. London: Kegan Paul.

“'Best Reader - D. Natsagdorj Distinction' Award Competition.” 2016. Chingis Khaan Odont, MUSGZ G. Mend-Ooyoogiin Neremjit Sükhbaatar Aimgiin Niitiin Nomyn San. https://aimaglibrary.wordpress.com.

Billé, Franck. 2015. Sinophobia: Anxiety, Violence, and the Making of Mongolian Identity. Honolulu: University of Hawai'i Press.

"Byambajargal, Losol." 2013. Oral History of Twentieth Century Mongolia. University of Cambridge. Mongolia and Inner Asia Studies Unit. http://amantuuh.socanth.cam.ac.uk/.

Charleux, Isabelle. 2015. Nomads on Pilgrimage: Mongols on Wutaishan (China), 1800 1940. Leiden: Brill.

Chimid, D. 2016. "Supporting Text: Notes on the Trip to Germany, From Leningrad to Germany" [Barimtat Zokhiol: German Ulsad Yavsan Zamyn Temdeglel, Leningradaas Germand Khödölsön]. In Four Chimids from the Thirties [Guchaad On, Dörvön Chimid], edited by Yadambatyn Baatar, 42-47. San Francisco: Private Collection.

Christianson, David. 2018. A History of Russia, Central Asia and Mongolia, vol. 2. Hoboken, NJ: Wiley Blackwell.

Damdinsüren, T. 1961. Foreword [Orshil]. In D. Natsagdorj's Works [Zokhioluud], edited by T. Damdinsüren, 5-6. Ulaanbaatar: State Publishing House. 
Dashbalbar, O. 2008. The Battle for Our Land Has Begun: Poems and Political Writings, 1990-1999 [Gazryn Tölöö Tulaldaan Ekhellee]. Translated by Simon Wickhamsmith. Ulaanbaatar: Dashbalbar Foundation.

Dorj, Z. 2011. Works Abandoned, but Not Wasted/Ideas Rejected, but Not Repressed [Khasagdavch Üregdeegüi Zokhioluud, Khayagdavch Daragdaagüi Tokhioluud]. Ulaanbaatar: Ukhaarlyn Khötöch.

Elverskog, Johan. 2006. Our Great Qing: The Mongols, Buddhism and the State in Late Imperial China. Honolulu: University of Hawai'i Press.

Kaplonski, Christopher. 2004. Truth, History and Politics in Mongolia: The Memory of Heroes. London: Routledge.

Maiskii, Ivan M. 1921. Contemporary Mongolia. Translated by Mrs. Dayton and J. Kunitz. eHRAF World Cultures. New Haven, CT: Human Relations Area Files. http://ehraf worldcultures.yale.edu.

“Mongol Khemeekh.” (2019). Mongolian Language Center [Mongol Khelnii Töv]. Facebook Post. www.facebook.com/mltrc.edu/.

"My Homeland" [Minii Nutag]. 2019. Wikipedia. https://mn.wikipedia.org/wiki/.

Natsagdorj, D. 1961. Works [Zokhioluud]. Edited by T. Damdinsüren. Ulaanbaatar: State Publishing House.

Pickles, John. 2004. A History of Spaces: Cartographic Reason, Mapping and the GeoCoded World. London: Routledge.

Pratt, Mary Louise. 2008. Imperial Eyes Travel Writing and Transculturation. 2nd ed. London: Routledge.

Sharav, C. 1984. "Dashdorjiin Natsagdorj." In Reader [Unshikh Bichig], edited by B. Myagmar, 137-38. Ulaanbaatar: Ministry of Education.

Sneath, David. 2018. "Mapping and the Headless State: Rethinking National Populist Concepts of Mongolia." In Mongolia Remade: Post-Socialist National Culture, Political Economy, and Cosmopolitics, 35-55. Amsterdam: Amsterdam University Press.

Sodnom, B. 1961. "D. Natsagdorj." In Works [Zokhiol], edited by Ts. Damdisüren, 7-23. Ulaanbaatar: State Publishing House.

- 1966. Dashdorj Natsagdorj's Biography and Works [Dashdorjiin Natsagdorjiin Namtar Zokhiol]. Ulaanbaatar: Ulsyn Khevleliin Khereg Erkhlekh Khoroo.

Smith, D. K. 2008. The Cartographic Imagination in Early Modern England. London: Routledge.

Spurr, David. 1993. The Rhetoric of Empire: Colonial Discourse in Journalism, Travel Writing, and Imperial Administration. Durham, NC: Duke University Press.

Tsedev, D. 2016. "Explanation of D. Natsagdorj's Original Manuscripts of Poetry” [D. Natsagdorjiin 'Yaruu Nairag'-iin Ekh Bichig Turshits Tailbar]. In Complete Works [Büren Zohiol], edited by D. Tsedev, vol. 1. Ulaanbaatar: Tsagaan Bambaruush.

"Welcome to Mongolian School of Colorado!" n.d. Mongolian School of Colorado. https:// mongolianschoolco.appspot.com/.

Wickhamsmith, Simon. 2020. Literature and Politics in Mongolia, 1921-1948. Amsterdam: Amsterdam UP.

Wolff, Serge. 1946. "Mongol Delegations in Western Europe, 1925-1929. Part 2." Journal of the Royal Central Asian Society 33: 75-92.

—. 1971. "Mongolian Educational Venture in Western Europe (1926-1929)." Zentralasiatische Studien 5: 247-320.

Youngs, Tim. 2013. The Cambridge Introduction to Travel Writing. Cambridge: Cambridge University Press. 